\title{
The Analysis of Popular Ending Mode Namely "After Suffering Comes Happiness" Reflected in Korean TV Series
}

\author{
Meiping $\mathrm{He}^{1, *}$ Mingzi Huang ${ }^{1}$ \\ ${ }^{I}$ School of Languages and Literature, Harbin Institute of Technology (Weihai), Weihai, Shandong, China \\ *Corresponding author. Email: hemeiping @ hit.edu.cn
}

\begin{abstract}
Film and television works not only spread the content, but also inherit national culture. Korean TV series not only wins the hearts of audience from Confucian cultural circle, but also reflects the characteristics of Korean national culture. The reason why Korean TV series are so popular with the audience is that the ending mode of Korean dramas, namely the "After Suffering Comes Happiness" mode, can reflect the public's yearning for a better life and greatly meet the psychological needs of the audience.
\end{abstract}

Keywords: South Korea, TV series, National culture, After Suffering Comes Happiness.

\section{INTRODUCTION}

With the development of economic globalization, the international exchanges and mutual influence of cultures are more and more profound. Communication in all fields is no longer limited by regions and national boundaries. Under the circumstances, the film and television works from various countries spread like a tidal wave.

Korea's film-television industry thrived in the 1990s, and then began to export TV series to its neighboring countries, triggering a boom in audience viewing, especially in China. After 2010, Korean films and TV series led to the "Korean wave" in China (Gao, 2015)[2]. The term "Korean wave" originated from wei chi and was later used to refer to the influence of Korean culture in other regions. Then it had an irreversible impact on the development of film-television industry in China. Chinese culture is the reservoir of "Korean wave". In 1997, when the Korean TV series What Is Love was broadcast on CCTV in China, Chinese have been in contact with Korean dramas for the first time. From then on, Chinese audiences have

*Funds: The stage results of science and technology university's international talent training research in foreign language majors under the initiative of Shandong province social science research special project "One Belt and One Road" (No.: 19CWZJ05). The work of Research and Innovation Fund Projects at Harbin Institute of Technology (Weihai), (20180912) gradually had high comments and expectations on Korean TV series.

\section{THE TRADITIONAL CULTURE EMBODIED IN KOREAN TV SERIES}

As one of the four Asian tigers, South Korea is historically connected with China, ranging from politics, economy to culture. Therefore, there is a close relationship between the two countries. China and South Korea not only face each other across the sea geographically, but also share similar cultures and languages. Before the Korean language was invented, People living on the Korean peninsula communicate with each other in traditional Chinese.

Both China and South Korea belong to the Asian cultural circle and have been continuously exchanging cultures with each other for hundreds of years (Zhao\& Zhu, 2018)[5]. The traditional culture reflected in many Korean TV series is the common embodiment of Chinese and Korean cultures. Confucianism is widespread and profound, which has continuously influenced the way of thinking and daily life of Chinese people and deeply rooted in China. In Korea, the profound influence of Chinese Confucian culture is also reflected in various aspects. Three quarters of South Koreans 
accept Confucian education and believe in Confucianism morally. This kind of Confucian culture is reflected incisively and vividly in Korean films and television series.

In The Beggar Prince, when family get home, peers or juniors should greet them at the door. Similarly, in The Bathhouse Men, the same scenes exist. When grandpa comes home, grandma will lead all the family standing at the door to welcome him back. However, when grandma comes back, it is her son, daughter-in-law and grandchildren who do so. When father comes back, mother do so, while mother is waited by the children and the elder sister is waited by little brothers and sisters. Besides, if the eldest brother visits his brother, his brother should stand at the door with his wife and children. Conversely, the former doesn't need to do such thing. This kind of greeting ritual is very common in many Korean TV series. Even when the father comes home, the children who are living on the second floor should go downstairs to greet him. In fact, it is a Chinese tradition to respect and greet the elders.

In terms of sitting, the respect for seniority is reflected in sitting orders and places. Usually, there is a very important position in the sitting room, which is prepared for the senior. For example, in Look and See, at Jifeng's home, if father is at home, that position will belong to dad and then it will belong to grandma and the eldest son. Commonly, the eldest son will ask his mother to sit. When just the two brothers are at home, the seat is brother's, while if their wives are at home, the brother's wife will enjoy that seat. The above is the matter of sitting places and the sitting order is as follows. The elderly sit first, and then are the junior, even the junior has already sat, they must stand up to wait for the elder to sit down. Finally, as for sitting posture, sitting in the seat without a chair, the elderly can sit more casually and men can be crosslegged. At the same time, women can stand crosslegged with one arm resting on the leg. However, the junior must be kneeling. If a junior makes a mistake and causes the elderly to be angry, he will need to stand up to apologize and wait for permission to sit down. There are so many rules just for sitting, but all of them inherit from Chinese traditional culture.

Many ancient historical TV series, such as Chengjunguan Gossip, Dae Jang Geum and Empress Myeongseong, have embodied the Confucian culture in every aspect, including filial piety, benevolence, loyalty and righteousness, making Confucian culture fully integrated into the plot and exerting a subtle educational effect on the audience. In My Love from the Star, a TV Series has been broadcast recently, there is a sharp contrast between plots in ancient time and modern time. However, the whole TV series does not break away from the Confucian culture of respecting the old and cherishing the young or respecting the superior and caring for the inferior(Zhang, 2017)[6].

However, most Korean TV series have happy endings. Therefore, it has almost formed a unified "after suffering comes happiness" mode. This kind of ending mode also stems from people's longing for a better life in ancient time, always starting with a good beginning and end with good results. This is a symbol of an ideal lifestyle.

\section{THE EMBODIMENT OF "AFTER SUFFERING COMES HAPPINESS" MODE REFLECTED IN KOREAN TV SERIES}

Since its emerging in the 1960 s, South Korean TV series has maintained a healthy and orderly development. In terms of its subject matter, the basic types can be roughly divided into historical plays, love plays and family ethics plays (Gao, $2015)^{[2]}$. As the years went by, the types of TV series are gradually richer and more diverse, with time travel plays, idol plays and so on emerging, among which most of the endings are the "after suffering comes happiness" mode.

The "after suffering comes happiness" mode can be called "happy ending" mode, that is, in order to meet the needs of the audience or readers' psychological happiness, the works are usually ended up with happy endings (Zhao, 2003)[4]. This "happy ending" mode prevails in every aspect of South Korea.

\subsection{The Perspective of Film-Television Industry}

It is film and television works that best reflect the "after suffering comes happiness" ending mode. Many of them from ancient times until now have ended with this kind of ending mode[7]. From What is Love originally introduced to China to the Toprated TV series Look and See and later Dae Jang Geum, Full House, My Name Is Kim Sam-sun, My Girl, Gung, Rooftop Prince, and then to My Love from the Star and Descendants of the Sun recently, without exception, all of them end with happy 
endings. Korean TV series is like a mirror, reflecting people's desire for film and television works embodying traditional culture, as well as their love for their own national culture and spirit.

\subsection{The Perspective of Literature}

This mode is not only reflected in film and television culture, but also can be found in Korean narrative literature in ancient times. The hero's tales in the ancient Korean founding myth tell us that all the heroes overcome all the sufferings through struggle and finally become winners. Later, this motif becomes the formulaic end of the hero tales. If the hero wins, he will be blessed and the contradiction between heaven and earth, god and man will no longer exist (Zhao, 2003)[4]. Thus, a realistic writing style based on distinct monism has emerged in Korean literature, which is naturally manifested as the protagonist's active pursuit of happiness.

\section{THE INFLUENCE OF KOREAN TV SERIES "AFTER SUFFERING COMES HAPPINESS" MODE ON CHINESE FILM-TELEVISION INDUSTRY}

\subsection{The Shift in TV Series Type}

In the 1980s, Chinese TV series types are mostly around the war, which is the mainstream theme, however, in 1993, for the first time Korean TV series Jealousy was introduced to China followed by Look and See in 1997 and then Korean wave surged in China. By 2004, South Korean TV series accounted for $16.4 \%$ of all the introducing foreign TV series in China (Zhang, 2009)[3]. Under the circumstances, China's TV series types gradually began to make a transition. In the 1990s, influenced by Korean TV series, Meteor Garden was released in China in 2001, which applied the typical "after Suffering Comes Happiness" mode and contained the Cinderella complex at the same time. In the 2000s, there were ancient romantic play Palace Scheming, wartime romantic play Almost a Love Story, It started with a Kiss introduced from Taiwan and Boss \& Me, Negotiator and other TV series recently. All of these TV series take the form of "after suffering comes happiness" ending under the influence of Korean TV series introduced to China.

\subsection{Psychological Impact on the Audience}

As a kind of mass media, Korean TV series need meet the "psychological needs" of Chinese audiences in order to take a large share of the Chinese film and television market after being introduced into China. First of all, the contents of South Korean TV series are mostly about family affection, friendship and love. Thanks to the extensive use of dramatically tensive elements, people of all ages can comfort themselves and release their emotions by means of the background and plot in the TV series (Tang, 2015)[3]. Especially, the "after suffering comes happiness" ending mode can strike a chord with the audience. Secondly, Korean TV series represent Korean culture, in which the most important culture is Confucianism. The atmosphere and traditional ideas presented in Korean TV series can resonate with Chinese audiences who can find the common culture in the society, which meets the public's needs for such social culture.

\subsection{Implications for the Future Development of Chinese Film- Television Industry}

The spread of Korean TV series in China is quite successful, whose successful introduction not only improves the cultural strength of South Korea itself, but also transmits various information and values to Chinese audiences and promotes the transformation of Chinese film-television industry. The reason why Korean TV series can earn the audience's recognition in China and even the whole world is that the various scenarios and plots can reflect reality and the real situations and feelings of ordinary people. In addition, the "after suffering comes happiness" mode can bring the audience a psychological comfort, because the sufferings of life can turn into a happy ending finally.

Therefore, China's film-television industry can absorb the essence of Korean TV series, formulate appropriate play theme making the psychological needs of Chinese people, and transmit China's national culture, clothing culture, food culture and so on to the world indirectly through film and television works. In this way, we can influence the thoughts of the audience, establish a unique Chinese style, spread distinctive culture, and further realize the inheritance of Chinese culture. 


\section{CONCLUSION}

China and South Korea are close neighbors geographically and both belong to the east Asian cultural circle, namely the "Confucian cultural circle" (Ding, 2015)[1]. This is one of the reasons why Korean culture is more easily accepted by Chinese audiences. However, the over-unification of the mode "after suffering comes happiness" makes the spread of Korean TV series have certain limitations. China needs to learn from the excellent and unique aspects of Korean film and television works, at the same time, win more film and television markets by means of integration of Chinese and western. Therefore, we can see Chinese culture is the reservoir of Korean culture. In the future, Chinese culture is very likely to lead the next cultural trend in the world.

\section{AUTHORS' CONTRIBUTIONS}

Meiping He was responsible for the conception and writing of the main content of the paper, and Mingzi Huang was responsible for the revision and inspection of the paper format.

\section{REFERENCES}

[1] Ding Mei. The Ethical Significance of South Korean Films and Television Plays [D]. Xi'an, Shanxi Province, China. Shaanxi Normal University. 2015.

[2] Gao Qiang. The Analysis of the Basic Types of Korean Drama [D]. Heilongjiang Province, China. Heilongjiang University. 2015.

[3] Tang Yuxing. The Analysis of Korean Idol Drama's Spread and Influence in China [D]. Chongqing, China. Chongqing Technology and Business University. 2015.

[4] Zhao Dongyi \& Xu Daxi. The Outline of Korean Literature $[\mathrm{M}]$. Beijing, Beijing University. 2003.

[5] Zhao Qianru \& Zhu Bi. The Analysis of Cross-cultural Communication in Korean Films and TV Dramas — Take Confucian Culture as Subject. House of Drama [J]. No.2, 2018, pp. 61-62.

[6] Zhang Honglian. A Comparison of Chinese and Korean TV Dramas from the Perspective of Oriental Culture. Movie Review. [J] No. 20, 2017, pp.69-71.
[7] Zhang Junwei. The Analysis of Cinderella Complex Reflected in Korean Series [D]. Xi'an, Shanxi Province, China. Northwest University. 2009. 